\title{
ARTICLE
}

Check for updates

\section{The fragility of rationality: George Eliot on akrasia and the law of consequences}

\author{
Patrick Fessenbecker (1) \\ Program in Cultures, Civilizations, and Ideas, Bilkent University, Ankara, Turkey
}

\begin{abstract}
George Eliot often uses the language of determinism in her novels, but we do not understand her view very well by treating such phrasing as addressing debates about the freedom of will directly. Instead she uses seemingly deterministic terms, like the 'law of consequences', to depict and analyse a particular problem in moral psychology: those instances where we ourselves make it impossible to act on our own best judgements. When we fail to act on our best judgement, this has downstream effects, since it can produce a gap between prudential rationality and one's all-things-considered judgement. Surveying depictions of this problem in Silas Marner, Adam Bede, and Romola, I argue that it's a revealing problem for Eliot's larger view, bringing together her objections to consequentialism, her recognition of the fragility of virtue, and her account of the role of sympathy in practical deliberation.
\end{abstract}

ARTICLE HISTORY Received 4 June 2020; Revised 11 September 2020; Accepted 1 September 2020

KEYWORDS Determinism; free will; sympathy; practical reason; Spinoza

Much of the scholarship on George Eliot over the last two generations has investigated with subtlety and care her attention to the tension between freedom and determinism. Taking its departure from George Levine's landmark 1962 article "Determinism and Responsibility in George Eliot" and more directly from Eliot's famous phrase from the end of Middlemarch, "there is no creature whose inward being is so strong that it is not greatly determined by what lies outside it", a variety of scholars have seen in Eliot nuanced analyses of the threats to a pre-reflective notion of free will by discoveries in the nascent social sciences and evolutionary biology (Middlemarch, 872). ${ }^{1}$ Attentive in particular to the way social norms constrained and produced women's behaviour in Victorian England, critics have

CONTACT Patrick Fessenbecker pfessenbecker@gmail.com

'Levine's diagnosis is that Eliot is a compatibilist: she believes in a 'rigidly determined' world but that moral responsibility is compatible with that fact when properly understood (269). That claim has generally been accepted; see for instance Beer, Darwin's Plots; Stone, "Chance and Ego", and Forrester, "Aiming to Hit". For a revisionary response, see Newton, "George Eliot, Kant, and Free Will". 
uncovered an Eliot who recognizes the determinative force of such norms but seeks ways of exerting meaningful human agency in spite of them. ${ }^{2}$

To a significant extent, attention to this philosophical problem is licensed by a consideration of her key terms and their sources in Eliot's reading during her formative period in the 1840s. Charles Bray's 1841 work The Philosophy of Necessity; or, The Law of Consequences explicitly sets out to debunk intuitive notions of freedom and show how seemingly free acts are the result of inevitable processes; as he puts it, "Motive is to voluntary action what cause is to effect in the physical, and the order of nature is as fixed in the world of mind as of matter" (Philosophy of Necessity, 171). Similarly, Robert William Mackay's 1850 The Progress of the Intellect - a review of which was Eliot's first contribution to the Westminster Review, when she was thirty-one - argues for the importance of scientific conceptions of law for social and cultural study. "The master key", Eliot writes,

is the recognition of the presence of undying law in the material and moral world - of that invariability of sequence which is acknowledged to be the basis of physical science, but which is still perversely ignored in our social organization, our ethics, and our religion.

(Essays, 31)

Human history is a series of experiments in the effects of the 'inexorable law of consequences,' and social improvement depends above all on comprehending that law.

But we do not grasp the nature of Eliot's philosophical project very clearly by putting it only in the light of her sources. ${ }^{3}$ When her narrators speak of the role of necessity in human actions and occasionally of their regulation by a 'law of consequences, the phrase denotes something quite different than a social or a biological structure constraining or producing human agency. In Eliot's hands, it names a specific problem in moral psychology: a particular species of akrasia, or action against one's intentions and judgements. While there is an inexorability to the law of consequences, it appears insofar as our previous actions constrain our present deliberations in ways we regret. A path dependency appears when - to pick a pattern Eliot returns to several times - I tell a lie, and then discover that despite my desire to be honest I must tell more lies in order for the first lie to have its intended effect.

There is certainly a sense in which the law of consequences interferes with my freedom, then, but it is not the freedom of choice unconstrained by social custom or biological impulse. Rather, the law of consequences prevents me from acting on the basis of the person I want to be, and is thus a threat to

\footnotetext{
${ }^{2}$ This tension is particularly complex with regards to Eliot's feminism, which was by no means straightforward. For a recent entry in the debate, see June Szirotny, The Right to Rebellion.

${ }^{3}$ This is a point Elizabeth Ermarth has brought out. She writes: "When she speaks of invariability of sequence George Eliot is usually making an analogy, not an identification between natural law and cultural law" ("Incarnations 277").
} 
something like my autonomy. But its force isn't anything external: it's just a past version of me, a version whose actions I regret. So Eliot's use of the language of metaphysical freedom ultimately is connected to what philosophers might now think of as the weakness of practical rationality. While it may be possible for agents to act on the basis of their best judgements, that capacity is fragile, and depends on maintaining one's character in such a way that one's interests don't become aligned with actions that violate those judgements. When they do become aligned - in other words, when one has to lie to keep a secret hidden - the law of consequences obtains, and the need to pursue a goal overcomes any principled commitment to honesty.

Eliot seems to have been particularly interested in this problem at the beginning of her novelistic career: Adam Bede (1859), Silas Marner (1861), and Romola (1862-3) all contain versions of it. The problem is presented in its simplest form in Silas Marner: in the character of Godfrey Cass, Eliot shows us one key akratic action, a second akratic action made necessary by the first, and the life-changing consequences that follow. Both Adam Bede and Romola expand significantly on this basic model: Adam Bede shows how the rational capacity in question is really the ability to sympathize with other people, and Romola shows how consequentialist deliberation without sympathy makes this kind of akrasia particularly likely. In other words, Eliot's thinking about akrasia and its causes is not an isolated project, but part of a broader analysis of the structure of the self closely connected to her overall thinking about the nature of sympathy and the process of moral deliberation. Elsewhere I have argued that Eliot's interpreters have significantly overstated the opposition between sympathetic impulse and rational deliberation, and that Eliot in fact views sympathy as an essential part of the self-mastery that makes it possible to overcome momentary impulses and act on the basis of a reason. ${ }^{4}$ What the akratic agents who suffer from the law of consequences ultimately demonstrate, then, is the kind of irrational heteronomy that comes with a selfish failure to sympathize with others.

Although the problem of akrasia has been recognized by many writers going back to Plato, the analysis of the problem in contemporary moral philosophy takes its departure from a key 1970 paper by Donald Davidson. ${ }^{5}$ Perhaps the major debates in recent years have taken place along three lines. First, whether akrasia is better understood as action against

\footnotetext{
${ }^{4}$ See my essay "Sympathy, Vocation, and Moral Deliberation in George Eliot", and particularly "The Scourge of the Unwilling: George Eliot on the Sources of Normativity", Chapter 4 of my book Reading Ideas in Victorian Literature: Literary Content as Artistic Experience.

${ }^{5}$ For an excellent review of the scholarship, see Stroud and Svirsky, "Weakness of Will". I discuss this scholarship as well in "Anthony Trollope on Akrasia, Self-Deception, and Ethical Confusion," Chapter 2 of Reading Ideas in Victorian Literature.
} 
one's best judgement or as action against a prior intention; to use the terms of the debate, whether akrasia and weakness of will are essentially the same or whether there is a significant difference between them (Holton, "Intention and Weakness of Will"; Mele, "Weakness of Will and Akrasia"). Second, whether and under what conditions akrasia can be rational - that is, whether there are moments in which one's best judgement is so mistaken about one's real interests that action against the best judgement is more rational than action in accord with it (Arpaly, Unprincipled Virtue). And perhaps the largest and most fundamental question stems from what's often called Davidson's internalism - the idea that judgements carry at least some motivational force (Stroud and Svirsky, "Weakness of Will").

George Eliot is not very interested in what one might call cases of classic, synchronic akrasia, where an agent acts against a judgement she consciously holds at the moment of its violation. She is slightly more interested in action against an intention, as we'll see in a moment, but what really draws Eliot's attention are the downstream effects of akrasia. Via such depictions she suggests that while it may be possible for judgements to carry motivational force, they do not do so of themselves. A self-constitution where one is motivated by principled judgements is surprisingly fragile, and does not happen accidentally or automatically. Correspondingly both rationality and akrasia are better understood as characteristics of the narrative history of individual lives, in which agents either succeed or fail at making it possible to act on the basis of their most important commitments.

To see this, let me briefly summarize the problem as it appears in Silas Marner. When Godfrey Cass appears in the novel's third chapter, it is with a significant backstory. Godfrey's brother Dunstan is successfully blackmailing him, and we quickly learn that Godfrey has secretly married and had a child with a poor opium addict named Molly Farren. He dares not let the secret emerge, however, because he dreams of marrying the principled Nancy Lammeter and still hopes that somehow it will be possible for him to do so. Thus he regards his marriage as a profound mistake:

A movement of compunction [...] had urged him into a secret marriage, which was a blight on his life. It was an ugly story of low passion, delusion, and waking from delusion, which needs not to be dragged from the privacy of Godfrey's bitter memory [...] And if Godfrey could have felt himself simply a victim, the iron bit that destiny had put into his mouth would have chafed him less intolerably. If the curses he muttered half aloud when he was alone had had no other object than Dunstan's diabolical cunning, he might have shrunk less from the consequences of avowal. But he had something else to curse - his own vicious folly, which now seemed as mad and unaccountable to him as almost all our follies and vices do when their promptings have long passed away.

(Silas Marner, 31. Henceforth SM) 
We see in this passage first of all a clear example of Eliot's subtle alteration to the language of metaphysical determinism. 'Destiny' has indeed placed an 'iron bit' in Godfrey's mouth, but what Eliot means by this is that Godfrey himself has given Dunstan the means of controlling him. And that's what Godfrey finds so maddening; had Dunstan found some other way to extract money it would have been less painful, because less dependent on and therefore less reminiscent of Godfrey's own mistakes. Sleeping with Molly was a momentary failure in which sexual desire deluded him, but that moment of akrasia has made more such moments inevitable. The narrator continues: "The yoke a man creates for himself by wrong-doing will breed hate in the kindliest nature; and the good-humoured, affectionate-hearted Godfrey Cass was fast becoming a bitter man, visited by cruel wishes" (SM, 31). The need to continually lie to keep his marriage secret is a burden that is changing Godfrey's character, reducing his kindness and introducing 'cruel wishes'.

Those wishes become clear later on, when Molly dies walking through the snow and her body is discovered outside Silas's cottage while her baby daughter Eppie is found inside. Godfrey, of course, is relieved - but that relief demonstrates how distanced he has become from his own principles. "There was one terror in his mind", the narrator writes; "it was, that the woman might not be dead. That was an evil terror [...] but no disposition is a security from evil wishes to a man whose happiness hangs on duplicity" (SM, 114). Because he has made dishonesty an essential virtue for the pursuit of his goals, Godfrey has correspondingly opened a place in himself for desires he would otherwise reject. Something about the way he has had to act is changing him: one way to put it is that he now cannot help but recognize the way certain events would benefit him, a fact that would ordinarily not enter into his assessment of possible futures.

A second akratic moment demonstrates this change. In lying to his uncle about why exactly he had to run through the snow to see a dead woman, Godfrey discovers he is good at deception. That by itself is indicative of his changing nature; as the narrator writes,

The prevarication and white lies which a mind that keeps itself ambitiously pure is as uneasy under as a great artist under the false touches that no eye detects but his own, are worn as lightly as mere trimmings when once the actions have become a lie.

$(\mathrm{SM}, 119)$

Previously, Godfrey has had the kind of honesty that reacted to even harmless untruths, but now he is different: his 'actions' have become a lie, and so merely verbal lies are hardly noticeable as moral failures. What it means for an action to be a lie is perhaps not immediately clear, but we can think of it as a failure of self-expression. Having lied as frequently as he has, 
Godfrey has lost ahold of the link between his principles and his behaviour, and thus his actions no longer express the person he wants to be.

This decision, the novel's climax, has an ironic consequence. Part of Godfrey's deception, of course, included denying that he was Eppie's father. But having married Nancy after Molly's death, he finds to his sorrow that they cannot have children. Godfrey proposes that they adopt Eppie, but discovers that his wife is adamantly opposed to adoption. Eventually circumstances compel Godfrey to admit that Eppie is in fact his child, an admission that leads Nancy to say something surprising:

Godfrey, if you had but told me this six years ago, we could have done some of our duty by the child. Do you think I'd have refused to take her in, if I'd known she was yours?

At that moment Godfrey felt all the bitterness of an error that was not simply futile, but had defeated its own end.

$(S M, 163)$

The key phrase here is an error that 'defeated its own end'. By denying that he had a child in order to have a child with Nancy, he made it impossible to do so, precisely because he did not understand what really mattered to the woman he wanted to marry. Having found himself in a state where his moral principles and his practical rationality seemed to dictate contradictory actions, he learns too late that the conflict was merely superficial. What seemed to be a tension between doing something for himself and doing something for others turns out to be quite different: it was actually a conflict between the immediate discomfort of admitting a secret marriage and (what he sees as) the long-term dissatisfaction of a childless marriage. Correspondingly the apparent dilemma between sympathy for others and rational pursuit of his goals turns out to also be merely apparent: had he sympathized more fully with Nancy, he would not have thought he faced a dilemma between benefiting himself and benefiting others. That's part of the problem the narrator alludes to in an early passage: we learn that Godfrey longs for "some tender permanent affection" that "would make the good he preferred easy to pursue" (SM, 31). In other words we mistake Godfrey's problem if we think of it in terms of emotion overcoming reason: what has happened rather is that Godfrey lacks the kind of emotional commitment that makes self-controlled action possible.

Two additional elements of Godfrey's moral psychology are worth noting, since they echo key points in Adam Bede and anticipate a theme of Romola. First, Godfrey is the kind of person who hopes and to a large extent believes everything will turn out well, even and especially if the path to that desired consequence is unclear; the narrator portrays this attitude as fundamentally connected to his akrasia. A belief in luck is a symptom of failure throughout Eliot's fiction, which as Jesse Rosenthal has demonstrated stems from her 
thinking about the nature of probability; as Rosenthal describes the mistake, it's "the failure to understand that though, over long enough time spans, certain statistical certainties will hold sway, such laws are not reducible to the individual case" ("Why George Eliot Hates Gambling", 802). Godfrey's failure is not that he believes in uncertainty but that he believes it will benefit him: "Favourable Chance is the god of all men who follow their own devices instead of obeying a law they believe in", the narrator explains; "the evil principle deprecated in that religion is the orderly sequence by which the seed brings forth a crop after its kind" (SM, 73-74.) That's to say the refusal to confront the likelihood of undesirable events stems from Godfrey's own inability to believe in and act on a law: an epistemic refusal to recognize 'orderly sequence' in the world follows from a volitional failure to give his life such an order.

Arthur Donnithorne in Adam Bede has a similar certainty: a "sort of implicit confidence" lets him believe that because he is "really such a good fellow at bottom, Providence would not treat him harshly" (Adam Bede, 344. Henceforth $A B$ ). The narratorial distance and corresponding cutting irony here is made especially apparent by a later passage where the narrator contends that in "young, childish, ignorant souls there is constantly this blind trust in some unshapen chance" (AB, 396-397). Like Godfrey, Arthur hides from the likely consequences of his actions, a sign to Eliot of his naiveté and egoism. More than in Godfrey Cass's case, however, Eliot shows via Arthur how this attitude is linked to a conviction of the praiseworthiness of one's character and to the general need for self-approval.

At the beginning of Adam Bede, Arthur is a young man whose life promises to be both good and happy. On the brink of inheriting a large estate in the England of 1799, he also has a much better relationship with the tenants than the current squire (his grandfather), and so believes that his personal success will also benefit the world. Indeed it is vital to his self-conception that this be true, for Arthur needs to believe that he is a good person: it is "necessary" for him "to be satisfied with himself" (AB, 289). So, when he starts a relationship with Hetty Sorrel, a girl whom he does not plan to marry, he cannot openly admit to himself that this is what he's doing. His conviction of his own fundamental decency prevents him from coldly assessing the likelihood of certain events - such as pregnancy - when such conclusions threaten his positive self-evaluation.

Flirting with Hetty in her home at the novel's opening, Arthur recognizes that he is falling in love with her and resolves not to see her alone again. But somehow he finds himself walking in a place where she is likely to be, at a time when she is likely to be there. "Nothing could be more natural," he thinks to himself: "meeting Hetty was a mere circumstance of his walk, not its object" $(A B, 143)$. After a clandestine meeting he again resolves to end the relationship, only to find himself subsequently finding, embracing, and 
kissing her. Yet Arthur is dissatisfied himself with himself all the while, and refuses to consider the logical consequences of letting the relationship continue: "irritated and mortified," the narrator explains, "he no sooner fixed his mind on the probable consequences of giving way to the emotions which had stolen over him to-day [...] than he refused to believe such a future possible for himself" (AB, 151). The volitional failure of meeting Hetty akratically stems from and is caused by an epistemic failure in recognizing what is likely to happen.

This is the point conveyed in a striking passage via the Reverend Irwine, an Anglican clergyman who figures as something like the novel's conscience. Arthur goes to Irwine to tell him that he is falling in love with Hetty, knowing that by saying so he will make it impossible for the affair to continue. Unable to bring it up directly, Arthur asks Irwine whether a man who succumbs to a temptation after a struggle is better than a man who acts on the temptation with no struggle. Irwine's answer is decisive:

No, certainly; I pity him in proportion to his struggles, for they foreshadow the inward suffering which is the worst form of Nemesis. Consequences are unpitying. Our deeds carry their terrible consequences, quite apart from any fluctuations that went before - consequences that are hardly ever confined to ourselves. And it is best to fix our minds on that certainty, instead of considering what may be the elements of excuse for us.

$(A B, 188)$

Irvine's ideas are echoed and extended by the narrator after Arthur's relationship with Hetty is discovered by Adam:

Our deeds determine us, as much as we determine our deeds, and until we know what has been or will be the peculiar combination of outward with inward facts, which constitutes a man's critical actions, it will be better not to think ourselves wise about his character. There is a terrible coercion in our deeds, which may first turn the honest man into a deceiver and then reconcile him to the change, for this reason-that the second wrong presents itself to him in the guise of the only practicable right. The action which before commission has been seen with that blended common sense and fresh untarnished feeling which is the healthy eye of the soul, is looked at afterwards with the lens of apologetic ingenuity, through which all things that men call beautiful and ugly are seen to be made up of textures very much alike.

$(A B, 342)$

As George Levine notes, this line of thought calls attention to the way a recognition of deterministic sequences is itself a moral belief with effects on one's actions ("Determinism and Responsibility", 277). Rather than taking the causal role of one's emotions as a mitigating excuse, far better to recognize that an action may have unintended but unavoidable consequences, what Stefanie Markovits has called Eliot's "sense of the impossibility of 
controlling consequences in the world" (The Crisis of Action, 91). Of course, one of the consequences is the effect on moral agents themselves. They lose their ability to clearly assess the ethics of their actions when once they have acted wrongly, since 'the second wrong presents itself' as 'the only practicable right'. It is particularly here, then, where it is important to grasp the idiosyncrasies in Eliot's use of the language of determinism: what determines us is us. She is skeptical of the strength of moral character, and convinced that virtues must be reinforced if they are to be continually expressed in the agent's actions. And they are maintained by keeping our capacity for selfawareness free of the need to engage in self-deception in order to maintain self-approval.

As in Godfrey Cass's case, moreover, that capacity depends as much or more on an emotional state as it does on rational capacity - or, better, the rational capacity lacking is an emotional one. What Arthur loses, according to the narrator, is the 'blend of common sense and fresh untarnished feeling', the combination of which is the 'healthy eye of the soul'. The moral objectivity at stake here is more an ability to feel a certain way when regarding an action than it is the ability to deduce certain facts about it. A key scene in the novel demonstrates the capacity that Arthur no longer has easy access to, when he finds out that his good friend Adam Bede is in love with Hetty and wants to marry her:

The discovery that Adam loved Hetty was a shock which made him for the moment see himself in the light of Adam's indignation, and regard Adam's suffering as not merely a consequence, but an element of his error. The words of hatred and contempt - the first he had ever heard in his life seemed like scorching missiles that were making ineffaceable scars on him. All screening self-excuse, which rarely falls quite away while others respect us, forsook him for an instant, and he stood face to face with the first great irrevocable evil he had ever committed.

$(A B, 328)$

What's important here is the conjunction of three attitudes, which the narrator implies are interrelated and mutually constitutive. First, this moment shows Arthur seeing his action through Adam's eyes, which is to say that he sympathizes with him. That sympathy also shows Arthur the real nature of his own actions, cutting through his self-deception to show the genuine evil of his relationship with Hetty. Finally, he takes responsibility for the wrong he has done: Adam's suffering is not merely an random event that happened because of Arthur's actions but rather something that Arthur himself has brought about and for which he can be blamed. What this conjunction of attitudes implies is that Arthur's akratic pursuit of Hetty and his refusal to take responsibility for his actions stem from a more fundamental failure, albeit one not generally connected with the capacity for selfcontrol: Arthur has failed to sympathize. 
There is a massive literature parsing the philosophical influences on Eliot's thinking about sympathy, and this is not the place to review it in depth. ${ }^{6}$ But to pick up one thread, a number of critics have seen in Adam Bede evidence of Eliot's encounter with Spinoza. ${ }^{7}$ This line of thought has recently received a significant resource in the publication of Eliot's translation of Spinoza's Ethics, making it possible to see more exactly how she understood his thought. And certainly, her depiction of the nature of akrasia and selfcontrol agrees with Spinozistic themes. First of all, Spinoza decisively rejects accounts that portray the body as a thing controlled by the mind: those who think this "know not what the body can do" (Spinoza's Ethics, 166). We believe that we are free in moments when we are 'conscious of our actions', but akrasia shows us otherwise. The moments when moral agents "struggle with contrary desires", and "see the better and follow the worse", demonstrate that we are not controlled by a "free determination of the mind" (Spinoza's Ethics, 167). ${ }^{8}$

This claim becomes more explicit in Spinoza's definition of love. In Eliot's translation, the passage reads: "I do not mean by will a consent of the mind, a deliberate purpose or a free decision [...] but by will I understand a satisfaction of the being who loves in the presence of the beloved object" (Spinoza's Ethics, 211). Will in this instance is not well understood as an authority that stands apart from a desire and authorizes it; rather, it is itself a certain way of experiencing the desire, a comfort with acting on the desire that augments the pleasure that comes with satisfying it. And finally self-control is not well understood as the capacity to act on the basis of moral principles even when they conflict with one's happiness. Instead, as both Godfrey and Arthur realize, acting on the basis of such principles is in fact the best way to be happy. In Spinoza's phrase according to Eliot, "To act absolutely from virtue is nothing else in us than to act, to live, to preserve our being (three things which are essentially one) according to the guidance of reason, on the basis of each seeking his own good" (Spinoza's Ethics, 243). To understand myself and what is good for me is also to want it, and there need be no distinction between doing what I want and doing what is good.

But one might note that there is a tension in the account of moral deliberation elaborated so far. On the one hand, Eliot seems to be insisting on the

\footnotetext{
${ }^{6}$ For a brief and clear survey of this scholarship, see Albrecht, Ethical Vision, 14.

${ }^{7}$ The scholarship here is indebted to Dorothy Atkins's 1978 book George Eliot and Spinoza, and has been extended by Moira Gatens in a number of ways; see "Art and Philosophy" and "Imagination and Belief". The comparison has been carried out further by a number of other critics, including James Arnett, Virgil Nemoianu, and Ted Zenzinger, and is likely to expand in the future in the wake of the recent publication of George Eliot's translation of Spinoza's Ethics. See Clare Carlisle's Introduction to this volume for a clear survey of the topic.

${ }^{8}$ In discussing Spinoza's account of akrasia I am indebted to two recent essays on the topic; see Marshall, "The Problem of Akrasia" and Lin, "Spinoza's Account of Akrasia".
} 
importance of objective, even mathematical analysis: one has to recognize and not shy away from the likely results from a given action. On the other hand, she also gives the impression that this kind of self-effacing awareness isn't really the essential feature: what matters more than probabilistic calculations is the emotional capacity to share the perspectives of other people, and thus to recognize when one's actions don't take their intended shape. That tension is not trivial or accidental. It stems from Eliot's complex reaction to John Stuart Mill's consequentialism, and her worry that simplistic forms of consequentialist deliberation make akrasia more likely rather than less.

To briefly recall the broad strokes of this view, John Stuart Mill (1806-73) was the dominant figure in mid-Victorian moral philosophy and intellectual life, and the figure against whom Eliot developed much of her thought. He famously attempted to develop a less reductive version of Jeremy Bentham's utilitarianism, arguing that Bentham was correct to think the morality of an action ought to be assessed on the basis of whether it increased pleasure and minimized pain more than other alternatives, and that neither Bentham's reductive account of human pleasures nor his simplistic calculus for making decisions were essential to the view. ${ }^{9}$ A major problem for consequentialist theories, both in Mill's time and subsequently, was clarifying how exactly individuals were supposed to make decisions, given that calculating the possible consequences of every alternative in every decision seems obviously impossible. In an important recent book, Dermot Coleman has surveyed Eliot's worries about such views, noting that her basic objection - consequentialism is ultimately just a self-aware selfishness - is common across the genre of the so-called industrial novel as a response to the fusion between utilitarian ethics and liberal economics in mid-Victorian England (George Eliot and Money, 79). But what is unique is Eliot's analysis of the moral psychology involved, in which the calculation of probable consequences actively hinders moral awareness.

Romola takes up these issues in Eliot's third sustained representation of the 'law of consequences'. In this iteration she is particularly interested in the gradualness of the descent into akrasia, showing how small detours from one's best judgement snowball and thus make larger detours rational. To briefly summarize the process, a young man named Tito Melema makes his way to Renaissance-era Florence after his ship has been attacked by Turkish pirates, and the central question in the beginning of the novel is whether Tito's companion and adoptive father Baldassare Calvo has been killed or instead captured and enslaved. The question is especially pertinent because Tito has a large set of jewels belonging to Calvo and thus enough money to find him and purchase his freedom. If, that is, he is still alive. At first, this seems like a genuine dilemma, and Tito's decision not to leave

\footnotetext{
${ }^{9}$ See Mill's essay "Bentham", in Utilitarianism and Other Essays.
} 
immediately but to invest the jewels and wait for more evidence seems reasonable if perhaps unnecessarily prudent. Eliot's narrator, however, warns the reader that Tito has

given an inevitable bent to his wishes. He had made it impossible that he should not from henceforth desire it to be the truth that his father was dead [...] The contaminating effect of deeds often lies less in the commission than in the consequent adjustment of our desires - the enlistment of our self-interest on the side of falsity.

(Romola, 100. Henceforth R)

The way this desire threatens Tito's moral psychology becomes obvious a few weeks later, when Tito receives a note from Baldassare confirming he is alive yet Tito refuses to go, thinking to himself: "the prospect was so vague [...] To spend months, perhaps years, in a search for which even now there was no guarantee it would not prove vain" (R, 115). The novel shows here how Tito's calculations suffer from motivated reasoning, as his analysis of the likelihood of success of a search for Baldassare depends upon an unspoken wish that such a search be unsuccessful.

When Baldassare himself appears in Florence and grabs his arm in a public square, Tito's moral psychology takes another twist. If he has been guilty of negligence before, Baldassarre's presence forces him into active wrongdoing. Tito cannot bring himself to act well - he experiences "that inexorable law of human souls, that we prepare ourselves for sudden deeds by the reiterated choice of good or evil which gradually determines character" (R, 223) - and he refuses to admit he recognizes Baldassare, calling him a madman. That's the trajectory leading to a crucial scene naming Tito's psychological state, where Baldassare confronts Tito at a party. The guests at the party try to test Baldassarre's identity and thus his accusation, but driven mad from his experience as a Turkish slave, he fails the test. Tito is of two minds about the experience:

so distinct sometimes is the working of a double consciousness within us, that Tito himself, while he triumphed in the apparent verification of his lie, wished that he had never made the lie necessary to himself - wished he had recognised his father on the steps - wished he had gone to seek him - wished everything had been different.

Tito has in a practical sense succeeded: he has stolen jewels from this man and concealed the crime. But in the moment of his success he wishes that none of it had happened. Like Arthur and Godfrey, actions have been reasonable to Tito that he wishes had not been reasonable. What is especially striking about this process, however, is how Eliot represents the moral deliberation at work. Because unlike Godfrey and Arthur, Tito thinks a great deal about the possible consequences of his actions. It simply turns out this makes things worse instead of better. 
One of Eliot's signature literary techniques is called 'free indirect discourse', a process of representing a character's thoughts without signalling that they are the character's. ${ }^{10}$ Often, the narrator passes back and forth between representing such thoughts and her own, at one moment commenting on them and at another letting the character's voice through without mediation. A remarkable passage shows Tito's deliberations in this way; I quote at length:

Certainly the gems and therefore the florins were, in a sense, Baldassarre's: in the narrow sense by which the right of possession is determined in ordinary affairs; but in that large and more radically natural view by which the world belongs to youth and strength, they were rather his who could extract the most pleasure out of them. That, he was conscious, was not the sentiment which the complicated play of human feelings had engendered in society. The men around him would expect that he should immediately apply those florins to his benefactor's rescue. But what was the sentiment of society? - a mere tangle of anomalous traditions and opinions, which no wise man would take as a guide, except so far as his own comfort was concerned. [...] Any maxims that required a man to fling away the good that was needed to make existence sweet, were only the lining of human selfishness turned outward: they were made by men who wanted others to sacrifice themselves for their sake. He would rather that Baldassarre should not suffer: he liked no one to suffer; but could any philosophy prove to him that he was bound to care for another's suffering more than for his own? To do so he must have loved Baldassarre devotedly, and he did not love him: was that his own fault? Gratitude! seen closely, it made no valid claim: his father's life would have been dreary without him: are we convicted of a debt to men for the pleasures they give themselves? Having once begun to explain away Baldassarre's claim, Tito's thought showed itself as active as a virulent acid, eating its rapid way through all the tissues of sentiment.

$(115-116)$

What Eliot shows us here is that Tito's consideration of two possible futures one in which he uses the money to rescue Baldassare, and one in which he keeps the money for himself - does not make the moral facts of his situation clearer to him. Instead, the act of reducing the dilemma to the bare question of who can 'extract more pleasure' from the gems serves to cut away many of the reasons he might otherwise recognize. The fact that the gems are Baldassare's does not matter; the fact that others would judge him is irrelevant; the fact that Baldassare raised him and might be thought to have some special call on his loyalty is ultimately inconsequential. After all, didn't Baldassare raise a child only for his own happiness? What matters is whose use of the gems will produce more pleasure, and Tito sees no reason to think he will enjoy them less than Baldassare. Understanding the situation in terms of a choice between possible happiness for Baldassare and possible happiness

\footnotetext{
${ }^{10}$ For an effective recent discussion of this technique and its connection to sympathy more generally, see Greiner, Sympathetic Realism.
} 
for himself thus appears as a technique for lying to himself about what his duties actually are. In Eliot's vivid metaphor, such thoughts are an 'acid' that dissolves all the moral feelings he would otherwise have recognized. This disintegration appears particularly in the way Tito's deliberation undermines the various deliberative factors, anticipating Nietzsche for instance in thinking that moral principles of self-sacrifice are merely a technique the powerful use to benefit themselves. It is not enough to simply set aside a particular factor: its normative basis has to be eliminated.

As with the case of Arthur Donnithorne, Tito's selfishness is interestingly correlated with two other failures. First, Tito becomes increasingly incapable of self-control in moments where his goals are frustrated. When for instance it appears his secrets will be discovered, he cannot do anything but wander around in the city, because "he was at one of those lawless moments which come to us all if we have no guide but desire" (R, 136). His autonomy is vulnerable, one might say: lacking the firm self-command that comes with a commitment to a principle of action, he is liable to being pulled in random directions when his pursuit of a desire is interrupted. Second and correspondingly, he becomes increasingly incapable of sympathizing with others, and therefore finds it more difficult to act intelligently when doing so requires understanding how others will react. As the narrator puts it:

it was impossible for him, shut up in the narrowness that hedges in all merely clever, unimpassioned men, not to overestimate the persuasiveness of his own arguments. His conduct did not look ugly to himself, and his imagination did not suffice to show him exactly how it would look to Romola.

The stupidity of egoism: consequentialist deliberation has cut off his emotional connection with others, and thus he is paradoxically less able to grasp what they will do and thus what consequences are most likely.

Thus while Tito's evolution demonstrates a different aspect of Eliot's thinking about moral psychology, ultimately his story fits with the view she developed in Adam Bede and Silas Marner. The capacity to sympathetically inhabit the perspectives of other people turns out to be an essential component of deliberative self-control. When Godfrey, Arthur, and Tito lose this emotional connection they lose the ability to act well, understood both as the ability to pursue their own interests effectively and to respect the interests of others. What Tito's narrative adds to the view developed in Eliot's earlier works is a response to a possible mistake about what it means to acknowledge the law of consequences. We do not properly understand this law if we think it simply means we ought not to trust to luck, the way Godfrey and Arthur do. Instead, the law of consequences is a thing grasped practically, a way of living that minimizes the possibility of self-imposed future dilemmas. 
Let me conclude by taking a step back and reflecting on how this account might be developed. Most immediately, it's worth noting that Eliot's objection to consequentialist theories of normative ethics is not a standard one. She is not troubled (or not only troubled) by consequentialism's failure to accord with common moral intuitions or its dismissal of concerns about justice; she instead objects to the basic act of deciding what to do by comparing the contributions to overall welfare made by various alternatives. And this is not just because such calculations are difficult, but because the mere act of considering possible benefits and harms of various alternatives encourages a careful accounting of how precisely various actions might benefit oneself. Attention to one's own benefit in this way cannot help but mislead moral agents, Eliot implies, for two reasons. First, because one will inevitably have more information about one's own circumstances than those of others, it will always seem that benefiting oneself is a more reliable way to increase overall welfare than benefiting others. Second and counterintuitively, careful accounting of one's welfare hinders clear perception of one's reasons, because it emphasizes the narrow benefits of immediate desire-satisfaction over the commitments and aspirations actually fundamental to human lives. This is to say the least a surprising worry - one might think that the simplicity of the utilitarian calculus makes it more resistant to selfdeception than other decision procedures - and one would like to know more about how Eliot would defend this objection and how a refusal to consider possible personal benefits interacts with basic norms of prudential rationality.

Then, too, the paradigmatic examples of akrasia in Eliot's mind are interestingly distinct from those common in the scholarship. She is not very interested in standard examples of weakness of will, and while she is more interested in actions that take place against one's intentions - as in the case of Arthur planning to end his relationship with Hetty and embracing her instead - such moments are preliminary stages to the real crises: selfimposed dilemmas where moral agents see how a particular problem could have been avoided if only they had acted in accord with their best judgement all along. What's useful about adding this kind of problem to the literature on akrasia is the way it makes clear how motivational force is within an agent's control even in moments where it appears otherwise. If classic akrasia occurs when an agent's motivational force is not aligned with her all-things-considered judgement, Eliot suggests this state is often a product of an agent's own deliberative history.

Finally and most broadly, there is a great deal more to say about the relationship between sympathy and rationality in light of Eliot's suggestion that the capacity to sympathize is constitutively related to the capacity to overcome akrasia. As I have somewhat briefly suggested here, for Eliot the clearest way to get ahold of oneself is to sympathize selflessly with other 
people, a capacity that makes it possible for us to look past the distraction of impulse and act on the basis of goals that genuinely matter. That claim introduces a number of questions, perhaps most fundamentally the observation that sympathy often involves an identification with others that does not clarify our goals but rather destabilizes our commitment to them, an aspect of sympathy to which many critics have argued Eliot was quite alive. ${ }^{11}$ Moral philosophy has in recent years returned to conceptions of the self similar to Eliot's, and perhaps that renewal will offer resources for puzzling out these and similar tensions in her enormously rich body of thought.

\section{Acknowledgements}

I wish to thank Alison Stone for the opportunity to participate here, and the two anonymous reviewers for their penetrating yet generous comments. I am grateful as well to Eileen John for inviting me to a workshop on George Eliot and philosophy at the University of Warwick, where I presented the first version of these ideas; the comments there from the extremely distinguished audience of Eliot scholars were very helpful.

\section{ORCID}

Patrick Fessenbecker (1D) http://orcid.org/0000-0002-4314-2872

\section{Bibliography}

Ablow, R. The Marriage of Mind Reading Sympathy in the Victorian Marriage Plot. Palo Alto, CA: Stanford University Press, 2007.

Albrecht, T. The Ethical Vision of George Eliot. London: Routledge, 2020.

Arpaly, N. Unprincipled Virtue: An Inquiry into Moral Agency. New York: Oxford University Press, 2003.

Arnett, J. "Daniel Deronda, Professor of Spinoza". Victorian Literature and Culture 44, no. 4 (2016): 833-54.

Atkins, D. George Eliot and Spinoza. Salzburg: Institut Für Englische Sprache und Litteratur, 1978.

Beer, G. Darwin's Plots: Evolutionary Narrative in Darwin, George Eliot, and NineteenthCentury Fiction. London: Routledge, 1983.

Bray, C. The Philosophy of Necessity; or, the Law of Consequences; as Applicable to Mental, Moral, and Social Science. London: Longman, 1841.

Carlisle, C. "George Eliot's Spinoza: An Introduction". In Spinoza's Ethics, edited by Clare Carlisle, 1-60. Princeton, NJ: Princeton University Press, 2020.

Coleman, D. George Eliot and Money: Ethics, Economics, and Literature. Cambridge: Cambridge University Press, 2014.

Eliot, G. Silas Marner: The Weaver of Raveloe. London: Penguin, 1996.

Eliot, G. Romola. London: Penguin, 1996.

\footnotetext{
${ }^{11}$ See especially Ermarth, "George Eliot's Conception of Sympathy", and Ablow, The Marriage of Minds.
} 
Eliot, G. Middlemarch. London: Penguin UK, 2006.

Eliot, G. Adam Bede. London: Penguin, 2008.

Eliot, G. Essays. Ed. Thomas Pinney. New York: Routledge, 2015.

Ermarth, E. "Incarnations: George Eliot's Conception of Undeviating Law". NineteenthCentury Fiction 29, no. 3 (1974): 273-86.

Ermarth, E. "George Eliot's Conception of Sympathy". Nineteenth-Century Fiction 40, no. 1 (1985): 23-42.

Fessenbecker, P. "Sympathy, Vocation, and Moral Deliberation in George Eliot". ELH 85, no. 2 (2018): 501-32.

Fessenbecker, P. Reading Ideas in Victorian Literature: Literary Content as Artistic Experience. Edinburgh: Edinburgh University Press, 2020.

Forrester, A. "Aiming to Hit: Archery, Agency, and Doing as One Likes in Daniel Deronda". Victorian Review 44, no. 2 (2018): 215-31.

Gatens, M. "The Art and Philosophy of George Eliot". Philosophy and Literature 33, no. 1 (2009): 73-90.

Gatens, M. "Compelling Fictions: Spinoza and George Eliot on Imagination and Belief". European Journal of Philosophy 20, no. 1 (2012): 74-90.

Greiner, R. Sympathetic Realism in Nineteenth-Century British Fiction. Baltimore: Johns Hopkins University Press, 2012.

Holton, R. "Intention and Weakness of Will". The Journal of Philosophy 96 (1999): 241-62.

Levine, G. "Determinism and Responsibility in the Works of George Eliot". PMLA 77, no. 3 (1962): 268-79.

Lin, M. "Spinoza's Account of Akrasia". Journal of the History of Philosophy 44, no. 3 (2006): 395-414.

Markovits, S. The Crisis of Action in Nineteenth-Century English Literature. Columbus: Ohio State University Press, 2006.

Marshall, E. "Spinoza on the Problem of Akrasia". European Journal of Philosophy 18, no. 1 (2008): 41-59.

Mele, A. "Weakness of Will and Akrasia". Philosophical Studies 150, no. 3 (2010): 391404.

Mill, J. S. Utilitarianism and Other Essys. Ed. Alan Ryan. New York: Penguin, 1987.

Nemoianu, V. "The Spinozist Freedom of George Eliot's Daniel Deronda". Philosophy and Literature 34, no. 1 (2010): 65-81.

Newton, K. M. "George Eliot, Kant, and Free Will". Philosophy and Literature 36, no. 1 (2013): 441-56.

Rosenthal, J. "The Large Novel and the Law of Large Numbers; or, Why George Eliot Hates Gambling". ELH 77, no. 3 (2010): 777-811.

Spinoza, B. Spinoza's Ethics. Trans. Marian Evans. Ed. Clare Carlisle. New York: Princeton University Press, 2020.

Stone, W. "The Play of Chance and Ego in Daniel Deronda". Nineteenth-Century Literature 53, no. 1 (1998): 25-55.

Szirotny, J. George Eliot's Feminism - the Right to Rebellion. London: Palgrave Macmillan, 2015.

Stroud, S., and L. Svirsky. "Weakness of Will". In The Stanford Encyclopedia of Philosophy (Fall 2019 Edition), edited by Edward N. Zalta. 2008. https://plato.stanford.edu/ archives/fall2019/entries/weakness-will/.

Williamson, A. "Against Egology: Ethics and Style in George Eliot and Emmanuel Levinas". The George Eliot Review 48 (2017): 33-47.

Zenzinger, T. "Spinoza, Adam Bede, Knowledge, and Sympathy: A Reply to Atkins". Philosophy and Literature 36, no. 2 (2012): 424-40. 